Ann. rheum. Dis. (1961), 20, 186.

\title{
PUERPERAL HYPERURICAEMIA
}

\author{
BY \\ B. L. J. TREADWELL AND A. St.J. DIXON \\ From the Postgraduate Medical School and Hammersmith Hospital, London
}

Elevation of the serum urate levels is well recognized in association with pregnancy toxaemia (Schaffer, Dill, and Cadden, 1943; Chesley and Williams, 1945; Chesley, 1950; Czaczkes, Ullmann, and Sadowsky, 1958). During a study of the incidence of familial hyperuricaemia in toxaemia of pregnancy, a persistent but gradually diminishing hyperuricaemia was noted in a proportion of the patients during the puerperium.

\section{Method}

Acceptance to this series as toxaemia of pregnancy was controlled by a rise of blood pressure to $140 / 90$ on at least three occasions, previous readings having been normal, or a rise to $140 / 90$ on one occasion with proteinuria in a previously normal urine. The serum urate was measured on the automatic analyser using Folin's reagent (Folin,

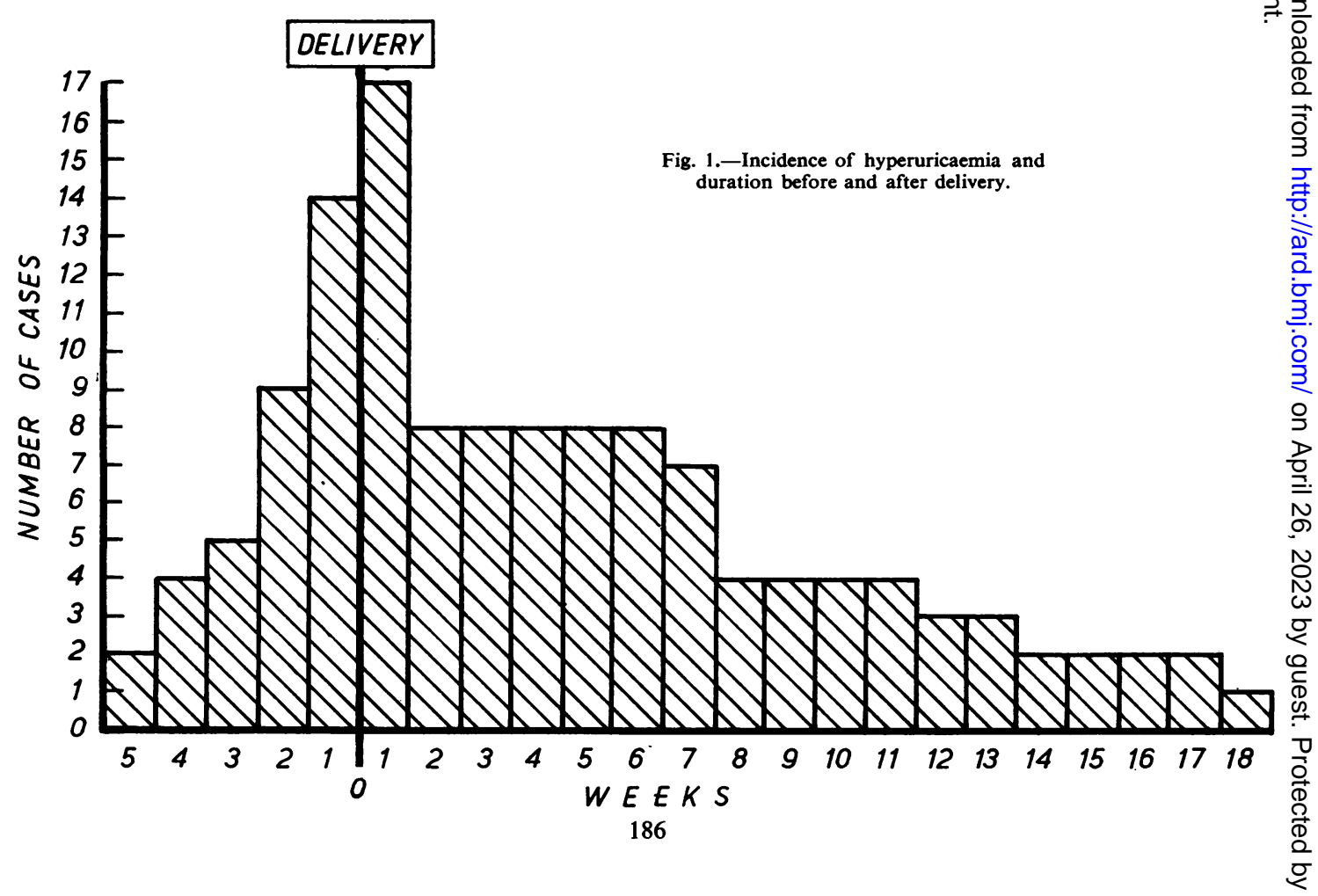


One patient had a serum urate level of $6.2 \mathrm{mg}$./ $100 \mathrm{ml}$. after 6 months and was considered to have persistent hyperuricaemia. Urate levels in all the other cases returned to normal.

Fig. 1 illustrates the incidence of hyperuricaemia and its duration in the weeks immediately before and after delivery. It will be seen that seventeen cases were hyperuricaemic during the first week post-partum, eight during the fourth week, four during the eighth week, three during the twelfth week, and two during the sixteenth week.

In Fig. 2 are shown three typical curves depicting toxaemic hyperuricaemia, before and after delivery.

\section{Discussion}

Hyperuricaemia initiated by pregnancy toxaemia is not described as continuing for more than a few days into the puerperium. Cadden and Stander (1939) found normal serum urate levels by the fourth post-partum day. Chesley and Williams (1945) observed that the diminished uric acid clearance in eight pre-eclamptics and two eclamptics returned to normal in all cases post-partum, but in two cases it persisted beyond the first week after delivery. Chesley (1950) noted that the uric acid clearance did not rise when the toxaemic syndrome abated with treatment and that it might drop before preeclampsia became apparent.

The finding in this series, of hyperuricaemia persisting, although gradually diminishing, in some instances for many weeks after the overt manifestations of toxaemia had subsided, was therefore unexpected.

The fact that probenecid increased urate excretion in pregnancy toxaemia even more than in controls (Czaczkes and others, 1958) suggests that, at least in the cases tested, severe cellular damage was not present. Handler (1960), in showing that the concentration of lactic acid in the blood of toxaemic patients is generally higher than in normal pregnant subjects, suggests that excessive circulating lactate may be partially responsible for the diminished urate clearance-at least during the toxaemic phase. It is difficult, however, to account for post-partum and puerperal hyperuricaemia on this basis, since lactate is rapidly metabolized.

In pre-eclampsia, the glomerular filtration rate and effective renal plasma flow are diminished, sometimes severely so. Pollak and Nettles (1960) have recently described both glomerular and renal tubular lesions in pre-eclampsia. They found a direct correlation between the height of the serum urate and the degree of glomerular disease, and state

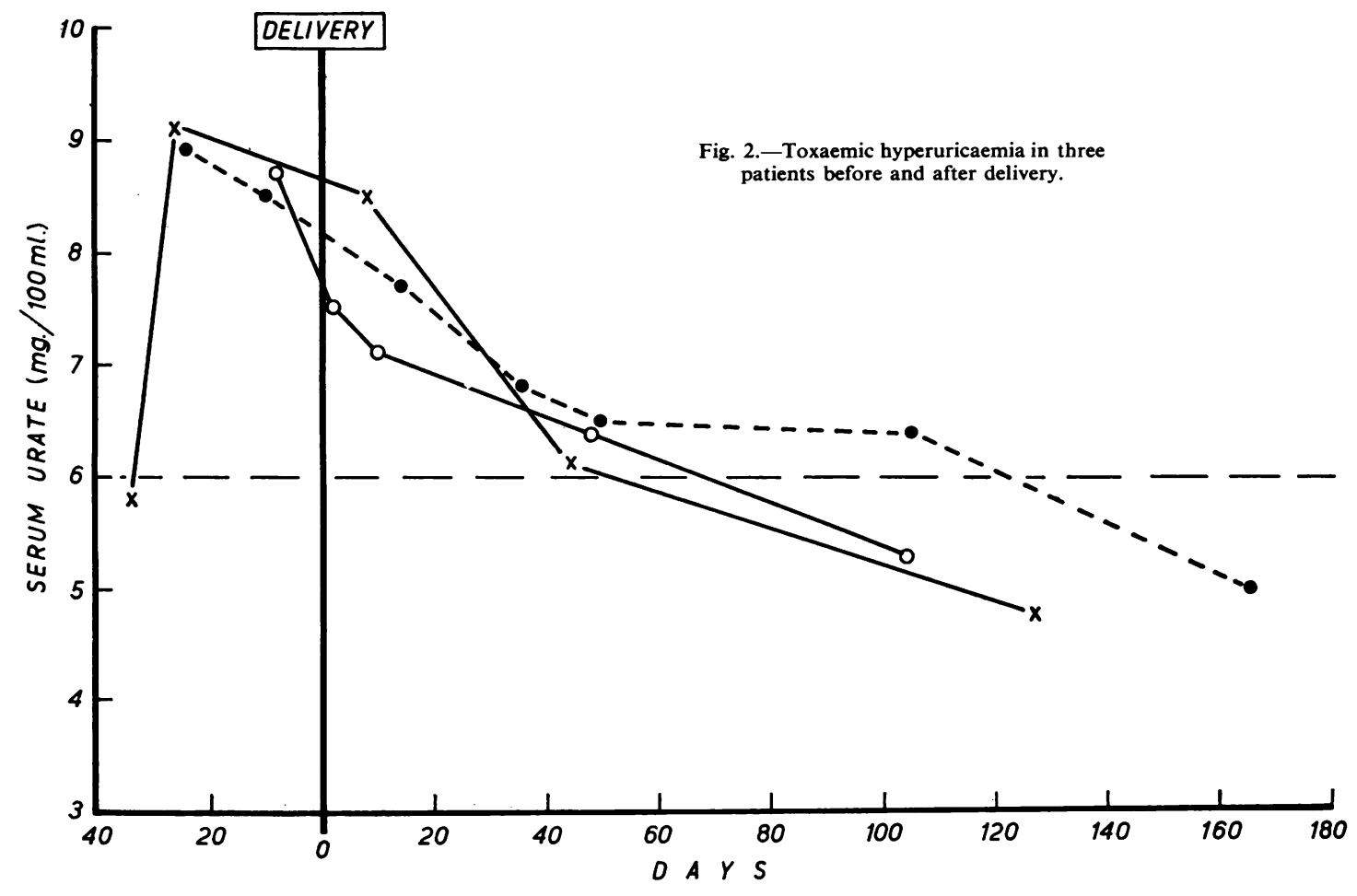


that "... no other clinical or biochemical parameter correlated as well with the glomerular pathology". Serial renal biopsies suggested that permanent glomerular damage occurred when there had been severe glomerular lesions with thickening of the basement membrane. Hyperuricaemia itself appeared to be responsible for progressive destruction of the nephron in the family reported by Duncan and Dixon (1960). The histology of the renal biopsies since obtained from the two youngest members was similar to that of chronic pyelonephritis. In that family hyperuricaemia preceded renal damage. However, it seems more likely that primary renal cellular damage-glomerular, tubular, or bothis at least partially responsible for toxaemic hyperuricaemia. Similarly, puerperal hyperuricaemia may reflect persisting histological changes.

\section{Summary}

Serum uric acid levels of $6 \mathrm{mg}$. per cent. or more were demonstrated in 23 ( 26 per cent.) out of 88 patients with pre-eclamptic toxaemia of pregnancy, and hyperuricaemia was shown to persist after delivery in seventeen cases for one week, in eight for 4 weeks, in four for 8 weeks, in three for 12 weeks, and in two for 16 weeks. One case remained hyperuricaemic 6 months post-partum. These results, together with the known decrease in glomerular filtration rate and effective renal plasma flow during pre-eclamptic toxaemia, and recent histological studies, suggest that renal cellular damage is responsible for toxaemic hyperuricaemia and that this damage may persist for a variable period into the puerperium.

\section{REFERENCES}

Cadden, J. F., and Stander, H. J. (1939). Amer. J. Obstet. Gynec., 37, 37.

Chesley, L. C. (1950). Ibid., 59, 960.

— and Williams, L. O. (1945). Ibid., 50, 367.
Czaczkes, W. J., Ullmann, T. D., and Sadowsky, (1958). J. Lab. clin. Med., 51, 224.

Duncan, H., and Dixon, A. St.J. (1960). Quart. J. Med., n.s. 29, 127.

Folin, O. (1934). J. biol. Chem., 106, 311.

Handler, J. S. (1960). J. clin. Invest., 39, 1526.

Pollak, V. E., and Nettles, J. B. (1960). Medicine (Baltimore), 39, 469.

Schaffer, N. K., Dill, L. V., and Cadden, J. F. (1943). J. clin. Invest., 22, 201.

\section{Hyperuricémie puerpérale \\ RÉSUMÉ}

Chez $23(26 \%)$ sur 88 femmes en état de toxémie pré-éclamptique on trouva dans le sang un taux d'acide urique de $6 \mathrm{mg} . / 100 \mathrm{cc}$. Ou supérieur et on observa que l'hyperuricémie persista après l'accouchement pendant une semaine dans 17 cas, pendant quatre semaines dans 8 cas, pendant huit semaines dans 4 cas, pendant douze semaines dans 3 cas et pendant seize semaines dans 2 cas. Dans un cas l'hyperuricémia se maintint pendant six mois après l'accouchement. Ces résultats, ainsi que la diminution bien connue de la filtration glomérulaire et de la circulation rénale effective du plasma pendant la toxémie pré-éclamptique, et les études histologiques récentes, font penser que l'hyperuricémie toxémique est due aux lésions cellulaires du rein et que ces lésions peuvent persister pendant une période puerpérale variable.

\section{Hiperuricemia puerperal Sumario}

Se encontraron en 23 (26\%) entre 88 enfermas co toxemia pre-eclampsica cifras de ácido úrico en sangrè de $6 \mathrm{mg}$. por cien e incluso superiores y sè comprobó que la hiperuricemia persistió después del parto una semana en 17 casos, cuatro semanas en 8 casos, doce semanas en 3 y dieciseis semanas en dos casos. En un caso la hiperuricemia perduró durante seis semanas después del parto. Estos resultados, junto con el conocido hecho de la disminución en la filtración glomerular y la circulación efectiva a través del riñon durante la toxemia pre-eclampsica, y recientes estudios histológicos, sugieren que la hiperuricemia toxémica es debida a alteraciones celulares renales y que dichas alteraciones pueden persistir por un periodo variable en el puerperio. 